\title{
Anticonvulsant properties of the total alkaloid fraction of Rauvolfia ligustrina Roem. et Schult. in male mice
}

\author{
Lucindo J. Quintans-Júnior ${ }^{1,2 *}$, Davi A. Silva², Jullyana S. Siqueira², Maria de Fátima \\ V. de Souza ${ }^{2}$, Reinaldo N. Almeida ${ }^{2}$, René G. C. Silva-Júnior ${ }^{3}$ \\ ${ }^{1}$ Departamento de Fisiologia, Universidade Federal de Sergipe, Campus Universitário Prof. Aloísio de Campos, \\ 49100-000, São Cristovão, SE, Brazil, \\ ${ }^{2}$ Laboratório de Tecnologia Farmacêutica, Universidade Federal da Paraíba, Cx. Postal 5009, \\ 58051-970, Paraíba, PB, Brazil, \\ ${ }^{3}$ Laboratório de Pesquisa do Vale do São Francisco, Universidade Federal do Vale do São Francisco, Cx. Postal \\ 252, 56306-410, Petrolina, PE, Brazil
}

\begin{abstract}
RESUMO: "Propriedades anticonvulsivantes da fração dos alcalóides totais de Rauvolfia ligustrina Roem. et Schult. em ratos machos”. Rauvolfia ligustrina Roem. et Schult. (Apocynaceae) é uma planta amplamente distribuída no Nordeste Brasileiro, rica em alcalóides indólicos, conhecida popularmente como "paratudo" e "arrebenta-boi". O presente estudo buscou avaliar a dose letal $50 \%\left(\mathrm{DL}_{50}\right)$ da fração de alcalóides totais (FAT) das partes aéreas da $R$. ligustrina e a sua possível atividade anticonvulsivantes em roedores. A FAT apresentou uma $\mathrm{DL}_{50}$, via intraperitoneal (i.p.), de 127,8 (112,5-145,2) mg/kg e foi efetiva, na dose de $20 \mathrm{mg} / \mathrm{kg}$ (i.p.), em proteger os animais das convulsões induzidas pelo pentilenotetrazol (PTZ) e picrotoxina (PIC) aumentando significativamente $(\mathrm{p}<0,05)$ a latência para o aparecimento das convulsões, sendo um indicativo de um efeito anticonvulsivante.
\end{abstract}

Unitermos: Rauvolfia ligustrina, anticonvulsivante, pentilenotetrazol, picrotoxina, eletrochoque auricular.

\begin{abstract}
Rauvolfia ligustrina Roem et. Schult (Apocynaceae), commonly known as "paratudo" and "arrebenta-boi" is a small tree found in Brazilian Northeastern. Previous studies have demonstrated depressant and anticonvulsant properties of the ethanol extract of Rauvolfia ligustrina. The aim of the present study was the determination of the lethal dose $50 \%\left(\mathrm{LD}_{50}\right)$ and the effects of total alkaloid fraction (TAF) of the aerial parts of $R$. ligustrina in animal models of convulsion. It was found that the acute toxicity of TAF was 127.8 (112.5-145.2) $\mathrm{mg} / \mathrm{kg}$ (i.p.) in mice. TAF $(20 \mathrm{mg} / \mathrm{kg}$, ip) significantly increased $(\mathrm{p}<0.05)$ the latencies of clonic seizures induced by pentylenetetrazol (PTZ) and picrotoxin (PIC). However, TAF did not protect the animals in maximal electroshock (MES) induced seizures. These results suggest that TAF of $R$. ligustrina possesses anticonvulsant properties.
\end{abstract}

Keywords: Rauvolfia ligustrina, anticonvulsant activity, pentylenetetrazol, picrotoxin, maximal electroshock.

\section{INTRODUCTION}

Bioactive alkaloids have been isolated from several plant species of the Apocynaceae family, including many belonging to the Rauvolfia genus. Species of Rauvolfia are rich sources of indole alkaloids (Kan et al., 1986; Cancelieri et al., 2002), such as reserpine that was isolated from Rauvolfia serpentina Benth. and has attracted interest on account of its pharmacological properties as an antihypertensive, anxiolytic, tranquilizing, inhibitors of the angiotensin converting enzyme and antiinflammatory activity (Woodson et al., 1957; Neuss, 1970; Lednicer; Mitscer, 1977; Barbosa-Filho et al., 2006a,b). Roots of Rauvolfia sellowii are used in folk medicine as an antihypertensive and the analysis of its crude extract has demonstrated some hypotensive activity in dogs (Batista et al., 1996). The extract from the root bark of Rauvolfia obscura showed antiamoebic activity (Tona et al., 1998).

Rauvolfia ligustrina Roem et. Schult (Apocynaceae) commonly known as "arrebenta-boi" and "paratudo", consists of a shrub widely distributed from South Mexico to the Brazilian Northeastern. All parts of the plant are poisonous (Agra et al., 2007). In preliminary behavioral screening by using the method described by Almeida et al. (1999), the ethanolic extract of the roots of $R$. ligustrina showed depressant activity on central nervous system (CNS) (Almeida et al., 2000). Furthermore, recent investigation provided evidence of possible anticonvulsant effect of the ethanol extract of the 
roots of Rauvolfia ligustrina in mice (Quintans-Júnior et al., 2002). In the present study, we determined the lethal dose $\left(\mathrm{LD}_{50}\right)$ and tested the effects of total alkaloid fraction of the aerial parts of $R$. ligustrina (TAF) in animal models of epilepsy.

\section{MATERIAL AND METHODS}

\section{Animals}

Male Swiss mice (25-30 g), with three months of age, were used throughout this study. The animals were randomly housed in appropriated cages at $25 \pm$ $2{ }^{\circ} \mathrm{C}$ on a $12 \mathrm{~h}$ light/dark cycle (lights on 06:00-18:00) with free access to food (Purina - Brazil) and water. They were used in groups of ten animals each. Experimental protocols and procedures were approved by the Laboratório de Tecnologia Farmacêutica Animal Care and Use Committee (Certidão/CEPA No 1105/06).

\section{Plant material}

The aerial parts of Rauwolfia ligustrina Roem et. Schult were collected in Santa Rita, Paraíba State in December 1994 and were identified by Dr. Maria de Fátima Agra (NPPN/UFPB). A voucher specimen (Agra19197) is deposited at the Herbarium Lauro Pires Xavier from Universidade Federal da Paraíba.

\section{Preparation of the extract}

Finely dried and powdered aerial parts of $R$. ligustrina were extracted with $95 \%$ aq. EtOH until a negative Mayer test, at room temperature. The EtOH extract was concentrated to dryness under reduced pressure. The resultant dried extract (400 g) was dissolved in $2 \mathrm{~L}$ of a $4 \%$ acetic acid solution and mechanically agitated during 2 hs. The suspension was filtered and the insoluble resinous matter discarded. The filtrate was partitioned with $\mathrm{CHCl}_{3}$ to yield, after evaporation to dryness, the acidic fraction (12 g). The acidic water phase was rendered alkaline ( $\mathrm{pH} 9$ ) with $\mathrm{NH}_{4} \mathrm{OH}$ and extracted with $\mathrm{CHCl}_{3}$. The organic layers were combined, washed with water and concentrated under vacuum to afford $4 \mathrm{~g}$ of the total alkaloids fraction of the aerial parts of $R$. ligustrina (TAF).

\section{Drugs}

Pentylenetetrazole (PTZ), phenytoin (PHE), picrotoxin (PIC), polyoxyethylene-sorbitan monolated (Tween 80) and Cremophor were purchased from Sigma (USA) and diazepam (DZP) from Roche (Brazil). The vehicle used in protocols was Tween 80 (0.2\%) with one drop of Cremophor. Agents were injected intraperitoneally (i.p.) with a dose volume of $1 \mathrm{~mL} / 100 \mathrm{~g}$.

\section{Determination of the lethal dose $50 \%\left(\mathrm{LD}_{50}\right)$}

Different doses of TAF (10, 20, 40, 80, 160 and $320 \mathrm{mg} / \mathrm{kg}$ ) were administered intraperitoneally (i.p.) to groups of male mice $(n=10)$. The groups were observed for $48 \mathrm{~h}$ and at the end of this period mortality was recorded for each group (Dietrich, 1983).

\section{Pentylenetetrazole (PTZ)-induced convulsion}

PTZ (60 mg/kg i.p.) was used to induce clonic convulsions (Swinyard et al., 1989; Oliveira et al., 2001). Animals were divided into five groups $(n=10)$, control group received vehicle and standard group was treated with diazepam (DZP, $4 \mathrm{mg} / \mathrm{kg}$ i.p.). The remaining groups were treated with 10, 20 and $40 \mathrm{mg} / \mathrm{kg}$ of TEF (i.p.). After 60 min of drug administration, the mice were treated with PTZ at a dose of $60 \mathrm{mg} / \mathrm{kg}$ (i.p.). Immediately after the injection of the convulsant, mice were individually placed in plastic polipropylene boxes and observed for the time onset of clonic seizures (latency), percent clonic seizures and deaths. The incidence of deaths was noted until $48 \mathrm{~h}$ after the injection of PTZ.

\section{Picrotoxin (PIC)-induced convulsion}

The method has been described previously (Lehmann et al., 1988; Ngo Bum et al., 2001). Animals were divided into five groups $(\mathrm{n}=10)$, control group received vehicle and standard group was treated with diazepam (DZP, $4 \mathrm{mg} / \mathrm{kg}$ i.p.). The remaining groups were treated with 10, 20 and $40 \mathrm{mg} / \mathrm{kg}$ of TEF (i.p.). After 60 min of drug administration, the mice were treated with PIC at a dose of $8 \mathrm{mg} / \mathrm{kg}$ (i.p.). Immediately after the injection of the convulsant, mice were individually placed in plastic boxes and observed for the time onset of clonic seizures (latency), percent clonic seizures and deaths. The incidence of deaths was noted until $48 \mathrm{~h}$ after the injection of PIC.

\section{Maximal electroshock test}

Maximal electroshock test (MES) that induces reproducible tonic convulsion characterized by tonic hindlimb extension (THE) was performed (Oliveira et al., 2001). In this experiment, electroconvulsive shock (130 V, 150 pulses/s, 0.5 s) was delivered through auricular electrodes (ECT UNIT 7801- Ugo Basile) to induced THE. Mice were divided into five groups $(n=10)$, control group received vehicle and standard group was treated with phenytoin (PHE, $25 \mathrm{mg} / \mathrm{kg}$; i.p.). The remaining groups were treated with 10,20 and $40 \mathrm{mg} / \mathrm{kg}$ of TEF (i.p.), similarly before experiment. After $60 \mathrm{~min}$ all groups received electroconvulsive shock. The animals that did not exhibit THE were considered protected (Tortoriello; Ortega, 1993). 


\section{Statistical analysis}

Calculation of the $\mathrm{LD}_{50}$ values with $95 \%$ confidence limits and comparisons of the results were performed using computerized linear regression analysis, in GraphPad Prism, version 3.02, a registered trademark of GraphPad Software Inc. The data obtained in experimental models were evaluated by one-way analysis of variance (ANOVA) followed by Dunnett s test. The incidence (\%) of clonic or tonic convulsions as well as the mortality were evaluated by Fisher`s Exact Test. Differences between means were considered to be statistically significant when $\mathrm{p}<0.05$.

\section{RESULTS}

\section{Determination of the $\mathrm{LD}_{50}$}

The $\mathrm{LD}_{50}$ for total alkaloid fraction of the aerial parts of $R$ ligustrina (TAF) with a $95 \%$ confidence limit, after (i.p.) administration was 127.8 (112.5-145.2) mg/kg in mice.

\section{Effects of TAF on PTZ-induced convulsion}

The TAF in dose of $20 \mathrm{mg} / \mathrm{kg}$ (ip) increased latency without protecting animals from clonic seizures. The pretreatment with DZP $4 \mathrm{mg} / \mathrm{kg}$ (ip) significantly

Table 1. Effect of TAF on convulsion induced by pentylenetetrazol.

\begin{tabular}{l|c|c|c|c}
\hline Treatment & Dose $(\mathrm{mg} / \mathrm{kg})$ & Latency $(\mathrm{s})^{\mathrm{a}}$ & \% Convulsions & \% Death \\
\hline Control & - & $109.0 \pm 9.0$ & 100 & 80 \\
DZP & 4 & $798.9 \pm 73.2^{\mathrm{c}}$ & $10^{\mathrm{d}}$ & $0^{\mathrm{d}}$ \\
TAF & 10 & $128.9 \pm 12.3$ & 100 & 70 \\
TAF & 20 & $329.4 \pm 95.6^{\mathrm{b}}$ & 80 & 80 \\
TAF & 40 & $195.1 \pm 73.2$ & 90 & 100 \\
\hline
\end{tabular}

$n=10$

${ }^{a}$ Values represent mean \pm S.E.M.

${ }^{\mathrm{b}} \mathrm{P}<0.05$ (one-way ANOVA and Dunnett's test), significantly different from control

${ }^{c} \mathrm{P}<0.01$ (one-way ANOVA and Dunnett`s test), significantly different from control

${ }^{\mathrm{d}} \mathrm{P}<0.01$ (Fisher`s test), significantly different from control.

Table 2. Effect of TAF on convulsion induced by picrotoxin.

\begin{tabular}{l|c|c|c|c}
\hline Treatment & Dose $(\mathrm{mg} / \mathrm{kg})$ & ${\text { Latency }(\mathrm{s})^{\mathrm{a}}}^{\mathrm{a}}$ & \% Convulsions & \% Death \\
\hline Control & - & $426.0 \pm 39.8$ & 100 & 100 \\
DZP & 4 & $1130.9 \pm 98.4^{\mathrm{c}}$ & $10^{\mathrm{d}}$ & $0^{\mathrm{d}}$ \\
TAF & 10 & $527.7 \pm 45.5$ & 100 & 100 \\
TAF & 20 & $677.8 \pm 81.3^{\mathrm{b}}$ & 90 & 80 \\
TAF & 40 & $574.0 \pm 67.1$ & 100 & 90 \\
\hline
\end{tabular}

$n=10$

a Values represent mean \pm S.E.M.

${ }^{\mathrm{b}} \mathrm{P}<0.05$ (one-way ANOVA and Dunnett`s test), significantly different from control

c $\mathrm{P}<0.01$ (one-way ANOVA and Dunnett`s test), significantly different from control

${ }^{\mathrm{d}} \mathrm{P}<0.01$ (Fisher`s test), significantly different from control.

( $\mathrm{p}<0.01)$ prolonged the latency and was effective in preventing clonic seizures induced by PTZ in $90 \%$ of the animals (Table 1)

\section{Effect of TAF on PIC-induced convulsion}

After receiving PIC (8 mg/kg i.p.), all mice of control group exhibited convulsions. The TAF in dose 20 $\mathrm{mg} / \mathrm{kg}$ (i.p.) failed to inhibit seizures, but significantly $(\mathrm{p}<0.05)$ prolonged the latency of the clonic seizures onset induced by PIC. The DZP (4 mg/kg i.p.) which was used as positive control, inhibited seizures in $90 \%$ of the animals (Table 2).

\section{Effect of TAF on MES}

As shown in Fig 1, the treatment of mice with TAF (10, 20 and $40 \mathrm{mg} / \mathrm{kg}$ i.p.) did not reduce the percent tonic hindlimb seizures. On the other hand, phenytoin (PHE, $25 \mathrm{mg} / \mathrm{kg}$; i.p.) antagonized MES-induced seizures.

\section{DISCUSSION}

Rauvolfia ligustrina (Apocynaceae) is a small tree found in Latin America (Rao, 1956). In preliminary behavioral screening using the method described by Almeida et al. (1999) the ethanol extract of the Roots of 


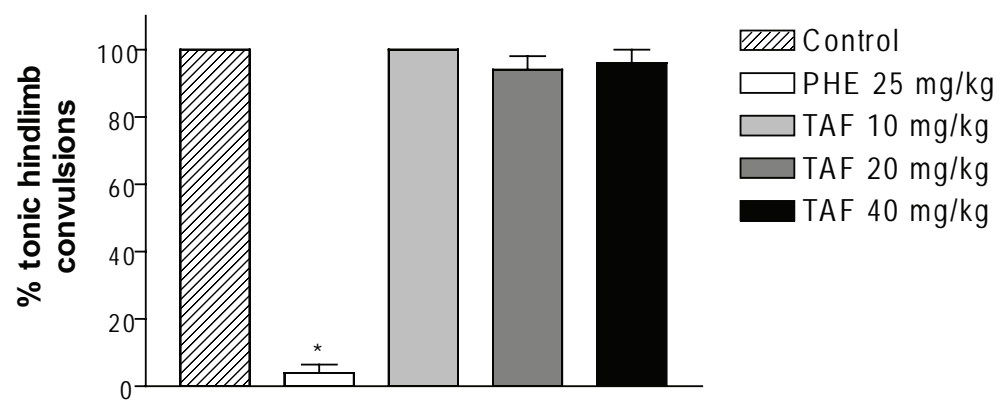

Groups

Figure 1. Effect of the TAF on MES-induced tonic hindlimb seizures in mice. The figure represents the percentage of animals that exhibit tonic hindlimb seizures induced by MES. * $\mathrm{p}<0.05$ (one-way ANOVA and Fisher`s test), significantly different from control.

$R$. ligustrina showed depressant activity on the central nervous system (CNS) (Almeida et al., 2000). In addition, Quintans-Júnior et al. (2002) reported evidence of the possible anticonvulsant effect of $R$. ligustrina in mice. The present study has determined the lethal dose $\left(\mathrm{LD}_{50}\right)$ and evaluated the anticonvulsant activity of the total alkaloid fraction of the aerial parts of $R$. ligustrina (TAF) against PTZ-, PIC- and MES-induced seizures in mice.

The respective $L_{50}$ of TAF was found to be 127.8 (112.5-145.2) $\mathrm{mg} / \mathrm{kg}$ in mice. Acute administration of TAF (20 mg/kg, i.p.) in PTZ-induced seizures significantly $(\mathrm{p}<0.05)$ increased the latency of clonic seizures onset in comparison with the control group (as shown in Table 1). PTZ-induced seizures test is considered as an experimental model for the "generalized absence seizures" (Oliveira et al., 2001). PTZ may cause seizures by inhibiting chloride ion channel associated with GABA ${ }_{A}$ receptors (Löscher; Schmidt, 1988; Almeida et al., 1998; Ngo Bum et al., 2001). Furthermore, PTZ might induce convulsions by direct excitatory effect upon membranes or by an antagonism of the effect of endogenous benzodiazepine substances (Faingold, 1987). Attenuation of the latency of clonic seizures onset in PTZ-induced seizures TAF (20 mg/kg, i.p.) suggests a possible anticonvulsant effect. The TAF $(20 \mathrm{mg} / \mathrm{kg}$, i.p.) also significantly increased $(\mathrm{p}<0.05)$ the threshold of clonic convulsions induced by PIC. The PIC induced seizures by blockade of chloride conductance associated to GABA ${ }_{\mathrm{A}}$ receptors (Faingold, 1987; N`Gouemo et al., 1994). Indeed, the TAF could not totally block seizures, however, the acute anticonvulsant efficacy of a drug does not necessarily predict its antiepileptic activity, which is measured by the ability of the drug to attenuate the epileptogenic process (Starr, 1996; Kasture et al., 2002).

The MES test is the most frequently used as an animal model for identification of anticonvulsant activity of drugs for the generalized tonic-clonic seizures "grand mal” (Löscher, 1998; Oliveira et al., 2001). This model based on observation of the stimulation by repeated electrical pulses induce in different neuronal structures one characteristic standard of epileptic activity (QuintansJúnior et al., 2002). The TAF could not demonstrate differences in comparison with the control group. Absence of anticonvulsant activities in the MES test suggest that TAF does not possess effect on this animal model in the used doses level.

Several mechanisms of anticonvulsant action have been proposed, but none enjoys general acceptance, including the increase of the concentration of biogenic amines (Oliveira et al., 2001). It is based on the fact that various anticonvulsants, by nonspecific depression of CNS function, increase the levels of serotonin in the brain (Korolkovas; Burckhalter, 1976; Dailey et al., 1996). Since bioactive alkaloids have been isolated from several species of the Rauvolfia genus including sources of indole alkaloids (Cancelieri et al., 2002), and as the 5-HT has indole nucleus in its structure, it might involve serotoninergic mechanisms of TAF. Nevertheless, the precise mechanisms underlying the inhibitory effect of TAF are not clear.

In conclusion, agents that have the ability of attenuating the appearance of seizures, might also have anticonvulsant ability. The TAF showed a possible anticonvulsant effect in two animal models of epilepsy. It also suggests that GABAergic and serotoninergic systems may be involved.

\section{ACKNOWLEDGEMENTS}

We thank Dr. M.F. Agra of the Botany section for collection and identification of plant material. The authors like to express their sincere thanks to R.N.S. Filho and J.C. Duarte for yours technical assistance. This work was supported by CNPq.

\section{REFERENCES}

Agra MF, França PF, Barbosa-Filho JM 2007. Synopsis of the 
plants known as medicinal and poisonous in Northeast of Brazil. Rev Bras Farmacogn 17: 114-140.

Almeida RN, Navarro DS, Assis TA, Medeiros A, Thomas G 1998. Antidepressant effect of an ethanolic extract of the leaves of Cissampelos sympodialis in rats and mice. J Ethnopharmacol 63: 247-252.

Almeida RN, Falcão ACGM, Diniz RST, Quintans-Júnior LJ, Polari RM, Barbosa-Filho JM, Agra MF, Duarte JC, Ferreira CD, Antoniolli AR, Araújo CC 1999. Metodologia para avaliação de plantas com atividade no sistema nervoso central e alguns dados experimentais. Rev Bras Farm 80: 72-76.

Almeida RN, Diniz SA, Diniz RST, Quintans-Júnior LJ, Barbosa-Filho JM 2000. Avaliação da toxicidade aguda e da atividade psicofarmacologica dos extratos etanólicos brutos de partes aéreas e raízes de Rauvolfia ligustrina. XVI Simpósio de Plantas Medicinais do Brasil, FM 194, pp 261.

Batista CVF, Schipsema J, Verpoorte R, Rech SB, Henriques AT 1996. Indole alkaloids from Rauwolfia sellowii. Phytochemistry 41: 969-973.

Barbosa-Filho JM, Martins VKM, Rabelo LA, Moura MD, Silva MS, Cunha EVL, Souza MFV, Almeida RN, Medeiros IA 2006a. Natural products inhibitors of the angiotensin converting enzyme (ACE). A review between 1980-2000. Rev Bras Farmacogn 16: 421446.

Barbosa-Filho JM, Piuvezam MR, Moura MD, Silva MS, Lima KVB, Cunha EVL, Fechine IM, Takemura OS 2006b. Anti-inflammatory activity of alkaloids: A twentycentury review. Rev Bras Farmacogn 16: 109-139.

Cancelieri NM, Vieira IJC, Schripsema J, Mathias L, Braz-Filho $\mathrm{R}$ 2002. Darcybeirine, a novel pentacyclic indole alkaloid from Rauvolfia grandiflora Mart. Tetrahedron Lett 43: 1783-1787.

Dailey JW, Yan QS, Adams-Curtis LE, Ryu JR, Ko KH, Mishra PK, Jobe PC 1996. Neurochemical correlates of antiepoleptic drugs in the genetically epilepsy-prone rats (GEPR). Life Sci 58: 259-266.

Dietrich L 1983. A new approach to practical acute toxicity testing. Arch Toxicol 54: 275-287.

Faingold CL 1987. Seizures induced by convulsant drug. In P.C. Jobe and H.E. Laird. II (Eds.) Naurotransmitters and Epilepsy. The Humans Press, Clifton, pp 215-275.

Kan C, Potier P, Kan S, Jokela R, Lounasmaa M 1986. Indole alkaloids from Rauvolfia media. Phytochemistry 25: 1783-1784.

Kasture VS, Kasture SB, Chopde CT 2002. Anticonvulsive activity of Butea monosperma flowers in laboratory animals. Pharmacol Biochem Behav 72: 965-972.

Korolkovas A, Burckhalter JH 1976. Anticonvulsants essential of medicinal chemistry. New York: Wiley, p. 105.

Lednicer D, Mitscer LA 1977. The organic chemistry of drug synthesis. John Wiley and Sons, New York, 317-320.

Lehmann J, Hutchison A, McPherson SE, Mondadori C, Schmutz M, Sinton CM, Tsai C, Murphy DE, Steel DJ, Williams M, Cheney DL, Wood PL 1988. CGS 19755, a selective and competitive $N$-metil-D-aspartate-type excitatory amino acid receptor antagonist. J Pharmacol Exp Ther 246: 65-75.

Löscher W, Schmidt D 1988. Which animal model should be used in the search for new antiepileptic drug? A proposal based on experimental and clinical consideration. Epilepsy Res 2: 145-181.

Löscher W 1998. New visions in the pharmacology of anticonvulsion. Eur J Pharmacol 342: 1-13.

Neuss R 1970. Chemistry of the alkaloids. Van Nortrand Reinhold Company S.W. Pelletier, p. 213-226.

N`Gouemo P, Nguemby-Bina C, Baldy-Moulinier M 1994. Some neuropharmacological effects of an ethanolic extract of Maprounea africana in rodents. J Ethnopharmacol 43: 161-166.

Ngo Bum E, Schmutz M, Meyer C, Rakotonirina A, Bopelet M, Portet C, Jeker A, Rakotonirina SV, Olpe HR, Herrling P 2001. Anticonvulsant properties of the methanolic extract of Cyperus articulatus (Cyperaceae). J Ethnopharmacol 76: 145-150.

Oliveira FA, Almeida RN, Sousa MFV, Barbosa-Filho JM, Diniz SA, Medeiros IA 2001. Anticonvulsant properties of $\mathrm{N}$-salicyloyltryptamine in mice. Pharmacol Biochem Behav 68: 199-202.

Quintans-Júnior LJ, Almeida RN, Falcão ACGM, Agra MF, Sousa MFV, Barbosa-Filho JM 2002. Avaliação da Atividade anticonvulsivante de plantas do Nordeste Brasileiro. Acta Farm Bonaerense 21: 179-184.

Rao AS 1956. A revision of Rauvolfia with particular reference to the American species. Ann Missour Bot Gard 43: 299-301.

Starr MS 1996. The role of dopamine in epilepsy. Synapse 22: 159-194.

Swinyard EA, Woodhead JH, White HS, Franklin MR 1989. Experimental selection, qualification and evaluation of anticonvulsant. In: Levy RH, Dreyfuss FE, Mattson RM, Meldrum BS, Penry JK, editors. Antiepileptic drugs. New York: Raven Press, p.85.

Tona L, Kambu K, Ngimbi N, Cimanga K, Vlietinck AK 1998. Antiamoebic and phytochemical screening of some Congolese medicinal plants. J Ethnopharmacol 61: 57-65.

Tortoriello J, Ortega A 1993. Sedative effect of galphimine B, a Nor-seco-triterpenoid from Galphimia galuca. Planta Med 59: 398-400.

Woodson RE, Youngken HW, Schlittler E, Schineider JA 1957. Rauwolfia: botany, pharmacognosy, chemistry \& pharmacology. Littler, Brown and Company, $1^{\text {st }}$ ed., 1-11. 